\title{
COMMENTS
}

\section{ORIGINALISM THROUGH RAZ-COLORED GLASSES}

\author{
LOUIS E. FELDMAN†
}

\section{INTRODUCTION}

A central aim of originalism is to provide judges with a valuefree theory of constitutional interpretation. Originalists want to restrain judges from independent consideration of the values and norms that ultimately justify any constitutional decision. When considering a constitutional issue, judges instead should defer first to the clear language of the Constitution, and second to the manifest intent of the framing generation for resolution of textual ambiguities. By binding judges to (1) an authoritative written text and (2) an authoritative theory of interpretation based solely on historical investigation, originalism seeks to define a judicial role that involves no independent examination of the moral issues underlying constitutional questions. The result is that an originalist judge substitutes the moral choices of the framers for his own when interpreting the Constitution. Since the moral balance was already struck by the framers, the judge is prevented from acting on any further consideration of the relevant moral issues.

But if judging is a rational process and if acting rationally is to act based on all the reasons that pertain to a particular decision, originalism must explain how it can be rational for a judge not to consider the moral dimension of constitutional questions. Originalists must contend with the question of how it is rational for the judge, in making a constitutional decision, to suspend consideration of factors that the judge knows to be relevant to interpretation of the constitutional text governing the decision. This question involves an examination of a more general question about authority: When is it ever rational for an agent to refuse to act on the balance of reasons that apply to a given situation, and instead simply to obey

† B.A. 1987, Temple University; J.D. Candidate 1992, University of Pennsylvania. My thanks to Frank Goodman, Heidi Hurd, and Michael Moore for their patience, encouragement, and counsel. My deepest appreciation to Karen Feldman for seeing me through this project. 
the dictates of another? Judicial deference to framers' intent exemplifies a general model of authority in which the subject does what he is told without independently considering the reasons for his actions, other than the fact that he has been so instructed.

This kind of authority is known as practical authority, a notion currently associated with the legal philosopher Joseph Raz. ${ }^{1} \operatorname{Raz}$ attempts both to clarify the notion of practical authority, and to explain when the grant of such authority is justified, such that the subject is obligated to obey. In this Comment, I explore whether Raz's theory of practical authority can provide originalists with a justificatory basis for the claim that judges should defer to the judgments of the framers when interpreting the Constitution.

Before examining the interpretive methodology that judges apply to constitutional adjudication it is necessary to note two questions that I do not address: whether the Constitution is a source of authority for judges, such that constitutional interpretation is a legitimate judicial enterprise; and what comprises the authoritative Constitution. $^{2}$ The question whether the Constitution itself is authoritative for judges is presumed to be answered in the affirmative. ${ }^{3}$ Regarding what is the authoritative constitution, I join

${ }^{1}$ Joseph Raz is "one of the great legal thinkers of our age." Martin L. Levine, Foreword, 62 S. CAL. L. REv. 731, 731 (1989). His works were the subject of a symposium, see Symposium, The Works of Joseph Raz, 62 S. CAL. L. REV. 731 (1989), and his recent book, JOSEPH RAZ, THE MORALITY OF FREEDOM (1986), has been described as coming "closer to the truth about political morality than anyone has for nearly a century." Donald H. Regan, Authority and Value: Reflections on Raz's Morality of Freedom, 62 S. CAL. L. REV. 995, 995 (1989).

Over the past several years, many other scholars have commented on, criticized, and debated the implications of Raz's analysis of political authority in terms of a theory of practical authority. See Larry Alexander, Law and Exclusionary Reasons, 18 PHIL. TOPICS 5 (1990); Heidi M. Hurd, Challenging Authority, 100 YALE L.J. 1611 (1991); Michael S. Moore, Authority, Law, and Razian Reasons, 62 S. CAL. L. REV. 827 (1989); Stephen R. Perry, Second-Order Reasons, Uncertainty and Legal Theory, 62 S. CAL. L. REv. 913 (1989); Frederick Schauer, Rules and the Rule of Law, 14 HARV. J.L. \& PUB. POL'Y 645 (1991); Philip Soper, Legal Theory and the Claim of Authority, 18 PHIL. \& PUB. AFF. 209 (1989).

2 The independence of these three questions (How should the Constitution be interpreted? Does the Constitution have authority? What is the Constitution?) has been noted by many constitutional scholars. See ERWIN CHEMERINSKY, INTERPRETING THE CONSTITUTION 25 (1987); WALTER F. MURPHY, THE NATURE OF THE AMERICAN CONSTITUTION 1 (1989); WALTER F. MURPHY ET AL., AMERICAN CONSTITUTIONAL INTERPRETATION at vi (1986); Michael S. Moore, Do We Have an Unwritten Constitution?, 63 S. CAL. L. REV. 107, 113-18 (1989); Larry Simon, The Authority of the Constitution and Its Meaning: A Preface to a Theory of Constitutional Interpretation, $58 \mathrm{~S}$. CAL. L. REV. 603, 606-07 (1985).

${ }^{3}$ According to Henry Monaghan, " $[t]$ he authoritative status of the written 
Justice Hugo Black, ${ }^{4}$ Edwin Meese, ${ }^{5}$ and Michael Moore ${ }^{6}$ in adopting the view that only the written text of the Constitution, what Moore calls the "syntactic Constitution," is endowed with authoritative status. The semantics of the Constitution, what that authoritative written text means, must be supplied by a theory of interpretation, but that determination must not be folded into the substance of the canonical Constitution. To do otherwise, to include within the notion of "Constitution" aspects of meaning, is to deprive the Constitution itself of authority, except to the extent that the text accords with an external standard of correctness. ${ }^{8}$ Presuming the authoritative status of only the written text of the

constitution is ... an incontestable first principle for theorizing about American constitutional law.... [T] $[$ he binding quality of the constitutional text is itself incapable of and not in need of further demonstration." Henry P. Monaghan, Our Perfect Constitution, 56 N.Y.U.L. REv. 353, 383-84 (1981); see also Ronald Dworkin, The Forum of Principle, 56 N.Y.U. L. REV. 469, 472 (1981) ("Any recognizable theory of judicial review is interpretive in the sense that it aims to provide an interpretation of the Constitution as an original foundational legal document."); Moore, supra note 2, at 113-14 (arguing that judicial review is legitimate only if based on the constitutional text); Richard S. Kay, The Bork Nomination and the Definition of "the Constitution, 84 Nw. U. L. REV. 1190, 1202 (1990) (book review) (arguing that even those who support "wide discretion in judicial review [are] unwilling to let go of the rhetorical support of the constitutional text").

Some of the arguments made in Part II.B. against according practical authority to the framers over constitutional interpretation, see infra notes $147-177$ and accompanying text, could be applied with equal force to the authority of the Constitution itself. There are other theories of authority, however, that could account for the authoritativeness of the Constitution without encountering the justificatory difficulties examined in Part II.B. See, e.g., Alexander, supra note 1, at 1920 (outlining a version of theoretical authority that might be called "as if" authority); Hurd, supra note 1, at 1615-28 (analyzing the theories of practical authority, influential authority, and theoretical authority and advocating the last); Moore, supra note 1, at 883-94 (proposing a theory of influential authority, which he refers to as "new reasons" authority); Regan, supra note 1, at 1011-18 (advocating a distinct theory of theoretical authority); Schauer, supra note 1, at 674-79 (arguing for a theory of "presumptive" authority).

As I will discuss in Part I.B., the problem for originalism is not that practical authority may not be a satisfactory account of political authority, but that originalism presumes the model of practical authority to describe the kind of deference judges must show to the framers. See infra notes $43-71$ and accompanying text.

${ }^{4}$ See Griswold v. Connecticut, 381 U.S. 479, 509-10 (1965) (Black, J., dissenting); HUGo L. BLACK, A CONSTITUTIONAL FAITH 10-11 (1969).

${ }^{5}$ See Edwin Meese III, The Law of the Constitution, 61 Tul. L. REv. 979, 981-82 (1987).

${ }^{6}$ See Moore, supra note 2, at 113-14.

7 Id. at 117.

${ }^{8}$ For a detailed account of this argument, see $i d$. at 117-18. But see Simon, supra note 2, at $619-30$ (implying that to give authority to the Constitution is actually to give authority to the principles that underlie it). 
Constitution, I focus on originalism through the powerful lens of Joseph Raz's theory of practical authority.

In Part I, I explain Raz's conception of practical authority and demonstrate that originalism implicitly adopts the Razian model to describe the relationship between the framers and the judge interpreting the Constitution. Based on his analysis of practical reason, Raz develops a general theory of practical authority and concludes that legal authority is a special case of practical authority. ${ }^{9}$ A working definition of practical authority is that when an entity possessed of practical authority issues an authoritative utterance, the subjects of that entity (those persons who are within the scope of the entity's authority) must treat the utterance as a sufficient reason for acting in accordance with the utterance; the subjects are not free to decide on their own whether what the entity has commanded is, all things considered, the right thing to do.

The practical authority model for legal authority is consistent with a jurisprudence of original intention. The originalist description of constitutional adjudication mandates that the judge treat the will of the framers, as manifested by their utterances, as sufficient reason for according to constitutional text the meaning implied by that will. The judge is barred from further inquiring whether the interpretation derived is, all things considered, the correct one. For the originalist judge, the framers are a binding practical authority. ${ }^{10}$

In Part II, I consider the possible justifications for according practical authority to the framers. I first describe Raz's justificatory arguments and then explore originalism's implicit rejection of those arguments. Raz's explanation of the legitimacy of practical authority is based on what he calls the "service conception" of authority. ${ }^{11}$ An entity's exercise of practical authority is legitimate only when that entity is a better weigher of reasons for action than the entity's subjects. ${ }^{12}$ While this "Normal Justification Thesis" implies a rather piecemeal obligation to obey the law for ordinary citizens, Raz's thesis yields a much broader obligation for judges to submit to law's authority. ${ }^{13}$ Nevertheless, originalists must reject Raz's justification of the exercise of practical authority, since the

${ }^{9}$ See infra notes 14-53 and accompanying text.

${ }^{10}$ See infra notes 54-85 and accompanying text.

11 See infra notes 86-89 and accompanying text.

${ }^{12}$ See infra notes $90-99$ and accompanying text.

${ }^{13}$ See infra notes $122-45$ and accompanying text. 
service conception of authority fails to provide judges with a binding, general obligation to obey. Although they implicitly adopt Raz's conceptual model of practical authority for the Constitution's framers, originalists must reject Raz's thesis that accounts for the legitimacy of granting such authority. I also examine in Part II other possible justifications for the framers' practical authority, in particular the notion of judicial restraint. Although I conclude that it is unlikely that originalism is capable of providing a justification sufficient for the sweeping authority that it demands judges accord to the framers, it is not the purpose of this Comment to engage in a polemic against originalism. Its purpose rather is to explore the intersection between constitutional interpretation and general legal theory. By testing the past decade's most debated method of constitutional interpretation against the precepts of the leading theory of law's authority, I hope to bridge the often daunting gap between general legal philosophy and applied jurisprudence.

\section{A Practical Model of Constitutional Authority}

\section{A. Raz's Model of Practical Authority}

Raz's account of authority attempts to explain how it can be rational to do as the law commands simply because the law commands. He believes that legal authority must be a particular example of practical authority, ${ }^{14}$ a special kind of relationship between two entities. $X$ has practical authority with respect to $Y$ if and only if $X$ 's utterances give $Y$ sufficient reasons to act in accordance with those utterances. ${ }^{15}$ This Part will explore Raz's conception of how a practical authority relationship manifests itself;

${ }^{14}$ See RAZ, supra note 1 , at 23-37. The belief that legal authority is a form of practical authority has traditionally dominated legal thought. See, e.g., RICHARD E. FLATHMaN, The PRACTICE OF POLITICAL AUTHORITY 90-91 (1980) (noting that anarchists, moderates, and conservatives have all subscribed to the model of practical authority); Hurd, supra note 1, at 1618-22 (observing that legal authority has usually been described in terms of practical authority).

Whether law's authority is best described in terms of practical authority is a debate within the larger dispute between legal positivists, who advocate a practical authority view of law, and natural law theorists, whose insistence on the necessary relationship between morality and law demands a rejection of any model of authority that deprives an agent of moral independence.

${ }^{15}$ See RAz, supra note 1, at 35, 37; see also Moore, supra note 1 , at 830 . The phrase "practical authority" refers to both this kind of authority relationship and the entity that possesses such authority. Thus, if $X$ possesses practical authority with regard to $Y$, then $X$ is a practical authority for $Y$. 
that is, how do a legal authority's commands obligate the law's subjects? Later, I will examine Raz's account of when an entity's claim of practical authority is legitimate. Since Raz's analysis of legal authority is predicated upon his description of practical reasoning, that is where I will begin.

Practical reasoning is the type of deliberation used to decide what ought to be done and how; it is the process of deciding what action, if any, ought to be taken in a given situation. Acting in accordance with the balance of reasons, all things considered, is fundamental to practical rationality. ${ }^{16}$ Accordingly, the answer to the question "What shall I do?" is always "That which is supported by the best reasons." 17 For any potential action there are reasons both for and against taking the action. These reasons may consist of values such as justice and fairness, the possible consequences of the action (both positive and negative), the existence of a prior promise to do the action, or any other consideration that bears on the justifiability of taking the action. Some reasons carry greater weight than others. A generally accepted model of rationality depicts a person as considering all these reasons, resolving any conflicts according to the relative weights of conflicting reasons, and acting on the balance. ${ }^{18}$

Reasons for action are either "content-dependent" or "contentindependent." A reason is content-dependent if there is some substantive connection between the reason and the action to which it pertains. Specifically, a content-dependent reason for action is a reason because the action it supports is correct on the merits. For example, the fact that it is raining is a content-dependent reason for taking along an umbrella when going outside, insofar as staying dry is better than getting soaked. On the other hand, a contentindependent reason is a reason for action regardless of the rightness of the action the reason encourages. According to Raz, a "reason

16 See Joseph Raz, Practical Reason and Norms 35-37 (2d ed. 1990); Hurd, supra note 1, at 1613 (citing Donald Davidson, How is Weakness of the Will Possible?, in MORAL CONCEPTS 93 (Joel Feinberg ed., 1969)).

${ }^{17}$ See RAZ, supra note 1, at 29; KURT BAIER, THE MORAL POINT OF VIEW 86-89 (1958).

${ }^{18}$ See RAZ, supra note 16, at 35; Hurd, supra note 1, at 1615-20. Note the similarity of this description to the "Hand Formula," which purported to quantify the negligence standard in tort law. See United States v. Carroll Towing Co., 159 F.2d 169 (2d Cir. 1947). An action is negligent (unreasonable or irrational) if the cost of not taking the action (the reasons for acting) is less than the product of the probability that harm will result from the action and the gravity of the harm that would result (the reasons against acting). 
is content-independent if there is no direct connection between the reason and the action for which it is a reason." 19 The authoritative status of the reason's source justifies a content-independent reason. When your mother asks you to take your umbrella with you when you go outside, your mother's request stands as a contentindependent reason for taking your umbrella, even if you know there is no chance of rain. ${ }^{20}$ In a sense, "content-independent" can be thought of as a label applicable to reasons for action produced by reason-generating machines (such as mothers). The reason-giving force of a content-independent reason derives from its pedigree, not its substantive content.

The reasons relevant to what one ought to do, all things considered, are objective, not subjective, because they need not motivate. You may even be totally unaware of the existence of a reason that figures in the balance of reasons. For example, if you wake up in the morning after a late night out on the town, and you just do not feel like going to work, you still have reasons to go to work (to meet your mortgage payments), even if you cannot remember those reasons or if they simply do not move you. ${ }^{21}$ Raz's theory requires that reasons for action be external to an individual's beliefs or desires, or to any set of universally shared subjective beliefs or desires. As Michael Moore writes: "Rather, it is morality that is reason-giving even if some, most, or all of us are too blind, too weak, or too immoral to be moved by such reasons." 22

Although Raz does not say so explicitly, the existence of objective reasons for action is essential to his explanation of legal authority as part of a general theory of practical reasoning. ${ }^{23}$ In Raz's view, the reasons supplied by morality have varying weights. When a person attempts to decide what he ought to do in the face of apparently conflicting reasons, he is (theoretically) able to arrive at a "correct" balance, since each reason should be counted according to its relative weight. Each person is then obligated to act in accordance with the result of such a balancing process. ${ }^{24}$

19 RAZ, supra note 1 , at 35.

${ }^{20}$ See Hurd, supra note 1, at $1616 \mathrm{n} .10$; see also RAZ, supra note 1, at 35-37.

${ }^{21}$ See RAZ, supra note 16, at 179-80 (suggesting that reasons have moral relevance regardless of one's awareness of or sensitivity to them).

${ }^{22}$ Moore, supra note 1 , at 842 .

${ }^{23}$ See id. at 843.

${ }^{24}$ See RAZ, supra note 16, at 27; Moore, supra note 1, at 845. 
Since Raz intends his explanation of how law obligates to be based on this general account of analytic morality (we are obligated to act rationally, in accordance with the balance of reasons for action), he needs reasons that have objective existence outside the context of merely subjective beliefs and desires. If reasons are subjective, they have no obligatory force..$^{25}$ An attempt to establish obligation by reference to subjective reasons-by positing that the only reasons we have for action are our own desires, and further that to be true to oneself one should act in accordance with those desires-retains the objective idea of being true to oneself. Obligation (or "oughtness") is impossible without objective reasons. Rejecting objective morality is certainly not unheard-of, ${ }^{26}$ but it is inconsistent with Raz's theory of legal obligation.

This model of rationality presents a problem for Raz's notion of practical authority. If the essence of rationality is to act on the balance of reasons, all things considered, how can it be rational to forego a balance of reasons analysis in favor of obeying the commands of a practical authority? Raz summarizes the paradox: "To be subject to authority, it is argued, is incompatible with reason, for reason requires that one should always act on the balance of reasons of which one is aware. ${ }^{27}$ Raz's solution to this paradox is that when it comes to practical reasoning and rationality, there are reasons, and then there are reasons.

Raz divides reasons into "first-order" and "second-order" reasons. A first-order reason is simply any of the reasons for action already discussed. A second-order reason is "any reason to act for a reason or to refrain from acting for a reason." 28 While firstorder reasons are reasons for action, second-order reasons are reasons for acting on reasons. "To conform to a second-order reason, in other words, it is not enough to do some specified action; rather, one must do the act for a certain reason." ${ }^{29}$ While the

${ }^{25}$ See RAZ, supra note 16 , at 34 (implying that while objective values provide generally applicable reasons for action that create obligations, desires and interests provide only subjective, non-obligatory reasons); see also RAZ, supra note 1, at 84 ("Reasons precede the will. Though the latter can, within limits, create reasons, it can do so only when there is a non-will-based reason why it should.").

${ }^{26}$ See Heidi M. Hurd, Note, Relativistic Jurisprudence: Skepticism Founded on Confusion, 61 S. CAL. L. REv. 1417 (1988) (discussing the prevalence of moral skepticism in legal theory).
${ }^{27}$ JOSEPH RAZ, THE AUTHORITY OF LAW 3 (1979).
${ }_{28} \mathrm{RAZ}$, supra note 16 , at 39 .
${ }^{29}$ Moore, supra note 1 , at 849 . 
"balance of reasons" view of rationality obtains for first-order reasons, it is inapplicable to second-order reasons. ${ }^{30}$

There are positive and negative second-order reasons. A positive second-order reason is a reason to act for a particular reason. A negative second-order reason is a reason to refrain from acting for a particular reason. ${ }^{31}$ Raz calls negative second-order reasons "exclusionary reasons," 32 and they play an important role in his theory of practical authority. Exclusionary reasons "are reasons for not being motivated in one's actions by certain (valid) considerations. ... They exclude reasons from being one's motivation for action .... ${ }^{n 3}$ According to Raz, an exclusionary reason requires that if a person acts, then that action must not be undertaken on account of a certain reason. Exclusionary reasons "change the moral landscape ${ }^{\text {34 }}$ by depriving first-order reasons of the moral force they would have in the balance of reasons, absent the exclusionary reason.

Whenever a conflict appears to arise between a second-order exclusionary reason and a contrary first-order reason, the secondorder reason prevails by virtue of being of a higher order. ${ }^{35}$ The conflict never actually arises, according to Raz, because no balancing of reasons is needed. ${ }^{36}$ The exclusionary reason does not defeat the contrary first-order reason by virtue of its greater weight. Instead, the exclusionary reason deprives the contrary first-order reason of any weight whatsoever, excluding it from being counted in the balance of reasons. ${ }^{37}$

Raz offers as an example of an exclusionary reason a father's order to his son that the son not act on his mother's instructions. The father's order is an exclusionary reason, because it gives the son a reason "never to take [his mother's] instructions as reasons for action." The father is not telling his son not to do the things that the mother instructs. The son may still act in accordance with his mother's instructions, and yet be obeying his father, so long as

\footnotetext{
${ }^{30}$ See RAZ, supra note 16 , at 36-40.

31 See RAZ, supra note 27, at 17.

32 Id.; RAz, supra note 16 , at 39.

${ }^{33}$ RAZ, supra note 16, at 185.

34 Moore, supra note 1 , at 850 .

${ }^{35}$ See Raz, supra note 16, at 46; Perry, supra note 1, at 913-14.

${ }^{36}$ See supra note 30 and accompanying text.

${ }^{37}$ See RAZ, supra note 16, at 36; Moore, supra note 1, at 850.

${ }^{38} \mathrm{RAZ}$, supra note 27 , at 17.
} 
the son does not act because of his mother's instructions. ${ }^{39}$ Before the father's order, the mother's instructions were relevant, first-order reasons for action in accordance with those instructions. After the father's order, the mother's instructions are excluded from consideration in the son's moral balancing of what action he ought to take.

Perhaps a more familiar example is this exhortation of Jesus to his disciples:

Beware of practicing your righteousness before men to be noticed by them; otherwise you have no reward with your Father who is in heaven.

When therefore you give alms, do not sound a trumpet before you, as the hypocrites do in the synagogues and in the streets, that they may be honored by men. ${ }^{40}$

The message is clear: it is right to give to charity, but wrong to give so that one "may be honored by men." Jesus's instruction provides (or at least, describes the existence of) an exclusionary reason not to consider the impression one will make when deciding whether to give to charity. You should not act for the reason that others will notice and honor you as a result of your action. The exclusionary reason of Jesus's exhortation deprives self-aggrandizement of any weight in the moral balance. ${ }^{41}$

The commands of practical authorities provide not only exclusionary reasons, but also new, content-independent first-order reasons for acting in compliance with those commands. The command of a practical authority is thus not only a first-order reason for acting in accordance with it, but it also excludes from consideration all conflicting first-order reasons. Raz labels this combination of a first-order reason and an exclusionary reason a "protected reason." 42 A reason is protected because it has no viable opponents when it is considered in the overall mix of reasons. ${ }^{43}$

An example of a law functioning as a protected reason is a sign posted on the edge of a field stating: "BY ORDER OF CITY

${ }^{39}$ See id.

${ }^{40}$ Matthew 6:1-2 (New American Standard Bible).

41 Note that under Raz's topology of reasons, the exhortation provides an exclusionary reason only if, absent the exhortation, self-aggrandizement would be a valid first-order reason. See RAz, supra note 16, at 183, 185.

42 See RAZ, supra note 27, at 18.

${ }^{43}$ See id.; Moore, supra note 1 , at 851 . 
COUNCIL, DO NOT WALK UPON THE GRASS.” Suppose it is a cold night in December and the grass is frozen solid. You can either obediently walk around the field or save yourself twenty minutes of struggling against a freezing wind. You are absolutely certain that no police are within miles. There are plenty of good reasons for cutting across the field; it is difficult to think of any good reasons why you should not. But the sign, speaking with the authoritative voice of the law, purports to provide just that: a perfectly good and sufficient reason not to cut across the field. According to Raz, not only does that sign give you a sufficiently good first-order reason not to spare yourself twenty minutes of misery, it also gives you an exclusionary reason to refrain from even taking into practical consideration your comfort when deciding whether or not to cross the field.

Armed with the concept of protected reasons, Raz develops a special description of how legal authorities function. This description is founded on two theses: the "Dependence Thesis" and the "Preemptive Thesis." 44 The Dependence Thesis states that "all authoritative directives should be based on reasons which already independently apply to the subjects of the directives and are relevant to their action in the circumstances covered by the directive. ${ }^{25}$ The Dependence Thesis is a moral thesis about how a legal authority should exercise its authority. ${ }^{46}$ The thesis establishes that legal authorities cannot be arbitrary in propounding laws, but must instead take into account all of the content-dependent first-order reasons for action that antecedently figured (or should have figured) in their subjects' practical reasoning.

If issued by a legal authority that complies with the Dependence Thesis, a law is a special kind of first-order reason. Each law "depends" on the antecedently existing first-order reasons that applied to the subjects before the law was passed. Laws thus "sum up" the antecedently existing balance of first-order reasons. Firstorder reasons that sum up the antecedently existing balance of firstorder reasons are called "dependent reasons." 47 The first-order

14 See RAZ, supra note 1 , at 41-53, 57-62.

$45 \mathrm{Id}$. at 47.

46 See id. at 53 .

47 See id. at 41 . The term "dependent reasons" also refers to the first-order reasons on which a reason depends. The context should make clear what meaning is appropriate. It is important not to confuse the terms "dependent reason" and "content-dependent reason." A law issued in accordance with the Dependence Thesis is a dependent reason, but it is also a content-independent reason because its 
reasons that legal authorities must consider when promulgating authoritative commands include justice, fairness, equality, democracy, liberty, and economy, among others. In short, legal authorities must promulgate laws that are dependent reasons based upon the universe of rule of law virtues, since these virtues are the antecedently relevant content-dependent first-order reasons for action in a just society. ${ }^{48}$

The complement to the Dependence Thesis is the Preemptive Thesis, which states: "the fact that an authority requires performance of an action is a reason for its performance which is not to be added to all other relevant reasons when assessing what to do, but should exclude and take the place of some of them.. ${ }^{49}$ This thesis follows from the Dependence Thesis. Because a law sums up the antecedently existing first-order reasons applicable to its subjects, the law's subjects are preempted from acting on those reasons. If the subjects were to consider the content-dependent first-order reasons on which the law depends in addition to considering the content-independent first-order reason provided by the law itself (which sums up the weights of those reasons), then they would be double-counting the antecedent first-order reasons.

Since a first-order reason should only be accorded its true weight, and since the law sums up the weights of all antecedently existing first-order reasons, the subjects are preempted from reconsidering those first-order reasons. As a consequence of the Preemptive Thesis, subjects faced with an authoritative command from a legal authority are precluded from considering the justificatory values that, according to the Dependence Thesis, underlie the command. The subjects are barred from looking to equality, justice, or any other rule of law virtue (or relevant value) when deciding what they ought to do. They must look to the command itself as the only reason for action.

A law is thus both a dependent reason and an exclusionary reason of a particular type. It is a reason to refrain from acting on the balance of antecedently existing first-order reasons on which the law depends. Laws are therefore protected reasons. In addition to

authority derives from its pedigree. The antecedently existing first-order reasons on which the law depends are content-dependent reasons, since their status as reasons derives from the merits of the actions for or against which they are reasons. See supra notes $19-20$ and accompanying text.

48 See RAZ, supra note 27, at 210-29; Michael S. Moore, A Natural Law Theory of Interpretation, 58 S. CAL. L. REV. 277, 291-94 (1985); Moore, supra note 2, at 112.

${ }^{49}$ RAZ, supra note 1 , at 46. 
being dependent, first-order reasons for action, the utterances of legal authorities constitute second-order exclusionary reasons that bar consideration of both the underlying content-dependent firstorder reasons that justify any action and any other contrary firstorder reasons. Laws therefore operate as content-independent reasons for action. ${ }^{50}$ For its subjects, a law's obligatory status is unrelated to notions of rationality or morality because by virtue of the Preemption Thesis, concerns about what makes something moral or rational (justice, fairness, liberty) are beyond the bounds of permissible consideration. ${ }^{51}$ The commands of legal authority stand as intermediaries between individual actors and the "right reasons which apply to them. ${ }^{n 52}$ People are thereby isolated from the values that ultimately justify their actions.

In sum, before the existence of a law relating to a particular action an agent has first-order reasons for and against taking the action. The passage by a legal authority of a relevant law gives the agent a new, content-independent, first-order reason for action that depends on the pre-existing content-dependent first-order reasons. In addition to being a first-order reason for action, the law provides a second-order, exclusionary reason to refrain from acting on the first-order reasons on which the law is dependent. The law is a second-order reason to exclude from the balance of first-order reasons all reasons relating to the action's justifiability, except for the first-order reason that the law itself demands the action. Thus, Raz's analysis of how legal authority obligates hinges on the capacity of legal authorities to create exclusionary reasons. ${ }^{53}$ Through his account of law's exclusionary reasons Raz explains the functional aspect of law's practical authority. The question remaining is when the exercise of such powerful authority is justified. I consider this question in the subsequent discussion of the legitimacy of constitutional authority.

${ }^{50}$ See supra note 20 and accompanying text.

51 This slightly overstates the point, since Raz maintains that abstract consideration of excluded first-order reasons is not barred, as long as they do not actually motivate. According to Raz: "There is no reason to prevent a person . . . from going through the [excluded reasons] to amuse himself or as an exercise, ... . so long as he does not . . . act on it." RAZ, supra note 16, at 48; see also RAZ, supra note 1, at 38-42; Joseph Raz, Facing Up: A Reply, 62 S. CAL. L. REV. 1153, 1157 (1989).

52 Joseph Raz, Authority, Law and Morality, 69 MoNIST 295, 299 (1985).

53 See Alexander, supra note 1 , at 5. 


\section{B. The Practical Authority of the Framers}

Having laid out Raz's conceptual model of practical authority, I turn my attention to originalism. Originalist interpretive theory adopts a view of the authority of the Constitution's framers vis-a-vis the judge equivalent to the judge's treating the framers as if they possessed Razian practical authority over the judge's interpretive decisions. An overview of the basic tenets of originalism will demonstrate the congruence between originalist notions of the authority of the framers and Raz's model.

As used in this Comment, "originalism" means that theory of constitutional interpretation that requires a judge to apply the Constitution according to an interpretation of the text that best represents the understanding of the "framers," those who drafted or ratified the Constitution and its amendments. ${ }^{54}$ Through diligent historical investigation, the judge must discover what the authors intended their words to mean and must be bound by that intended meaning when interpreting the Constitution's text. ${ }^{55}$ Justice Sutherland offered one of the clearest judicial expressions of the originalist position: "The whole aim of construction, as applied to a provision of the Constitution, is . . to ascertain and give effect to the intent, of its framers and the people who adopted it. ${ }^{n 66}$ Chief Justice Rehnquist has written that the role of the judge is to enforce the understandings and values that "may be derived from the language and intent of the framers." ${ }^{.57}$ According to Judge Bork, "the framers' intentions ... are the sole legitimate premise from which constitutional analysis may proceed. ${ }^{58}$ The judge is bound by the original intentions of "those who framed, proposed, and ratified" the Constitution and its amendments. ${ }^{59}$ Another

54 The term "originalism" was coined by Paul Brest. See Paul Brest, The Misconceived Quest for the Original Understanding, 60 B.U. L. REv. 204, 204 (1980). The term "interpretivism" is used by some scholars to refer to the same concept. See, e.g., Raoul Berger, Some Reflections on Interpretivism, 55 GEO. WASH. L. REV. 1, 1 (1986).

55 See Edwin Meese, Address Before the Washington, D.C. Chapter of the Federalist Society Lawyers Division (Nov. 15, 1985), in THE Great DebaTE: INTERPRETING OUR WRITIEN CONSTITUTION 31, 33-36 (1986) [hereinafter GREAT DEBATE].

${ }^{56}$ Home Bldg. \& Loan Ass'n v. Blaisdell, 290 U.S. 398, 453 (1934) (Sutherland, J., dissenting).

57 William Rehnquist, The Notion of a Living Constitution, 54 TEX. L. REv. 693, 695 (1976).

${ }^{58}$ Robert Bork, Tradition and Morality in Constitutional Law, in VIEWS FROM THE BENGH: THE JUdiciaRY AND CONSTITUTIONAL POLITICS 166, 171 (Mark W. Cannon \& David M. O'Brien eds., 1985).

${ }^{59}$ Robert Bork, Address Before the University of San Diego Law School (Nov. 18, 
originalist scholar similarly states that judges must apply "the rules of the written constitution in the sense in which those rules were understood by the people who enacted them. ${ }^{\text {60 }}$

In practice, when reviewing the constitutionality of legislation, the originalist judge is to look to the text of the Constitution, as understood by its drafters, and discern the "core value that the framers intended to protect. ${ }^{n 1}$ If the statute in question violates that "core value," it is unconstitutional. Otherwise, the legislation must stand. In determining how broadly to characterize the core value being protected the judge is bound to "choos[e] no level of generality higher than that which interpretation of the words, structure and history of the Constitution fairly support." ${ }^{n 2}$ The level of generality at which the core value is properly stated is thus precisely that level of generality intended by the framers. Originalist interpretive theory binds the judge to the framers' choices of which values are to be protected as well as the scope of protection, even if the language of the Constitution is general enough to accommodate protections broader than what can be fairly imputed to the framers from historical evidence.

A major consequence of originalism is that the will of the framers is at least as authoritative as the text of the Constitution. ${ }^{63}$ Indeed, originalists hold that the judge's oath of office entails a promise to enforce the intent of the framers. ${ }^{64}$ One originalist, Richard Kay, denies that judges owe their allegiance "only to the mere words of the Constitution." 65 They must defer instead to the "exercise of human will"66 that culminated in constitutional lawmaking. The originalist judge views the written text of the Constitution as a heuristic guide to uncovering the authoritative will of the framers. ${ }^{67}$

This approach to constitutional interpretation furthers one of the declared goals of originalism's advocates: judicial restraint.

1985), in GREAT DEBATE, supra note 55, at 43, 43.

${ }^{60}$ Richard S. Kay, Adherence to the Original Intentions in Constitutional Adjudication:

Three Objections and Responses, 82 NW. U. L. REV. 226, 230 (1988) (emphasis omitted).

61 Bork, supra note 59, at 46.

${ }^{62} \mathrm{Id}$. at 48 (emphasis added).

63 See RAOUL BERGER, GOVERNMENT BY JUDICLARY 368 (1977).

64 See, e.g., Edward J. Melvin, Judicial Activism-The Violation of an Oath, $27 \mathrm{CATH}$. LAW. 283, 284 (1982) ("WW]hen a judge takes his oath to uphold the Constitution he promises to carry out the intention of the framers.").

${ }^{65} \mathrm{Kay}$, supra note 60 , at 230.

${ }^{66}$ Id. at 232.

${ }^{67}$ See Brest, supra note 54, at 209 n.28. 
Most originalists believe that "any defensible theory of constitutional interpretation must demonstrate that it has the capacity to control judges." 68 Originalist theory restrains judges by restricting them to a value-free method of interpretation. Originalism demands that the judge adopt a posture of deference with respect to the framers; the judge is precluded from any independent consideration of substantive values when attempting to give meaning to ambiguous constitutional text. As President Ronald Reagan put it when he nominated Judge Bork for appointment to the Supreme Court: "[J]udges' personal . . . values should not be part of their constitutional interpretations. ${ }^{n 9}$ Rather, the judge is bound by the intentions of the framers, and the value choices implied thereby, in determining how to apply any given constitutional provision. Judge Bork and other originalists find fault with any interpretive method that, by giving effect to judges' value choices, encroaches on the supreme constitutional authority of the framers. ${ }^{70}$

The point of originalist interpretation is to apply only those values "constitutionalized by the framers," with no application of the values of the judge, or anyone else. ${ }^{71}$ The framers' intentions form an impenetrable barrier between the interpreting judge and considerations of substantive morality that otherwise would be relevant to the interpretive enterprise. The moral balance having already been struck by the framers, the judge is prevented from acting on further consideration of the otherwise relevant moral issues.

The deferential judicial posture demanded by originalism is equivalent to a requirement that the judge treat the framers as possessing Razian practical authority over the judge's interpretive

${ }^{68}$ Bork, supra note 59, at 45; see also MARK TUSHNET, RED, WHITE, AND BLUE: A CRITICAL ANALYSIS OF CONSTITUTIONAL LAW 23 (1988) ("[Originalism avoids] judicial tyranny. By confining the judges to the words of the Constitution as understood by the framers, we ensure that they will not go too far; we bar them from making decisions that in a democratic society are properly made by a political majority."); Berger, supra note 54, at 1 (commenting that interpretation does not give license to alter).

${ }^{69}$ President's Remarks Announcing the Nomination of Robert H. Bork to be an Associate Justice, 23 WEERLY COMP. PRES. DOC. 761 (July 1, 1987), reprinted in Robert H. Bork, THE TEMPtING OF AMERICA: THE POLITICAL SEDUCtIoN OF the LAW 267-68 (1990).

${ }^{70}$ See David A.J. Richards, Originalism Without Foundations, 65 N.Y.U. L. REV. 1373, 1377 (1990) (reviewing BoRK, supra note 69).

${ }^{71}$ Robert W. Bennett, The Mission of Moral Reasoning in Constitutional Law, $58 \mathrm{~S}$. CAL. L. REV. 647, 650 (1985). For a discussion of the value of judicial restraint in promoting democracy, see infra notes $178-90$ and accompanying text. 
enterprise. The judge is bound not only by the framers' authoritative utterance (the Constitution), but also by the framers' will (intentions). In the absence of authoritative framers' intent, judicial interpretation of facially ambiguous constitutional provisions necessarily involves an appeal to substantive values. ${ }^{72}$ These values, including democracy, liberty, separation of powers, fairness, and equality, ${ }^{73}$ constitute reasons for action that the judge would presumably balance in attempting to determine the meaning to assign to a given constitutional provision. ${ }^{74}$ They are reasons for action because the resultant balance would dictate how the judge should act in interpreting the language of the Constitution and applying it to the case at hand. For the originalist judge, however, evidence of framers' intent provides new reasons for action. In deciding how to interpret the text such a judge must take into account the core value implicated by historical evidence of the framers' understanding of the text's meaning. Furthermore, the framers' intentions bar the judge from basing his interpretive decision on consideration of values not specified in the historical record. In addition to providing the judge with new reasons to act, evidence of framers' intent provides the judge with exclusionary reasons to refrain from acting on the reasons given by substantive values. ${ }^{75}$

Presumably, the framers considered substantive issues such as justice and equality when they drafted the Constitution and formed their intentions regarding its meaning. Because the conclusions they reached sum up the weights of those values, an appeal to the framers' intent satisfies Raz's Dependence Thesis. ${ }^{76}$ It then follows from the Preemptive Thesis 77 that the judge must not reconsider those substantive values that informed the framers' moral balancing, else he would be guilty of double-counting. Additionally, the framers' intentions have exclusionary force. The judge is precluded from taking into account any considerations, moral or otherwise, that might militate against adopting the intent of the framers as the meaning of constitutional text. In sum, the judge must treat the intentions of the framers as giving what Raz

72 See Moore, supra note 2, at 112.

73 See id.

${ }^{74}$ See supra notes 16-18 and accompanying text (discussing the "balance of reasons" view of rationality).

${ }^{75}$ See supra notes 31-41 and accompanying text (discussing exclusionary reasons).

${ }^{76}$ See supra notes $44-48$ and accompanying text (discussing Dependence Thesis).

${ }^{77}$ See supra note 49 and accompanying text (discussing Preemptive Thesis). 
calls protected reasons for action when interpreting constitutional text. Original intent stands as a barrier between the interpreting judge and the substantive values that motivated those original intentions. ${ }^{78}$ The originalist conception of the relationship between the framers and the judge exactly tracks Raz's analysis of how practical authority works. ${ }^{79}$

An example of judicial deference to the practical authority of the framers is provided by Bowers $v$. Hardwick, ${ }^{80}$ in which the Supreme Court rejected a challenge to the constitutionality of a Georgia statute outlawing sodomy. The reasoning of this opinion has been characterized as evincing "a judicial posture of deference to external authority." 81 In Hardwick, the Supreme Court denied that it was engaging in any sort of moral balancing to determine, under the Fourteenth Amendment's Due Process Clause, the permissibility of Georgia's legal repression of homosexual sex. ${ }^{82}$ In disclaiming any reliance on substantive morality as a basis for constitutional interpretation, the Court insisted that it was bound by the moral decisions of those who drafted and ratified the Constitution. In determining that there is no "fundamental right" to engage in sodomy, the Court relied on the fact that sodomy "was forbidden by the laws of the original 13 States when they ratified the Bill of Rights," ${ }^{83}$ and that "when the Fourteenth Amendment was ratified, all but 5 of the 37 States ... had criminal sodomy laws." ${ }^{84}$ Given that there was no evidence that the drafters of the Fourteenth Amendment intended to protect a person's right to engage in homosexual sodomy (that is, as long as homosexual

78 See supra notes 50-52 and accompanying text (discussing protected reasons).

${ }^{79}$ It might be objected that my analysis is unfairly drawn and that I have set up a strawman version of originalism, since I focus almost exclusively on strict, intentionalist originalism rather than one of originalism's more pragmatic and flexible incarnations. This objection does not stand for two reasons. First, my analysis could, with some modification, be extended to encompass an interpretive methodology predicated upon original meaning or original understanding, or for that matter, any method of interpretation to the extent that it relies on appeal to an authoritative historical interpreter. See infra note 161. Second, the purpose of this Comment is not to undermine originalism, but to investigate the ramifications of applying Joseph Raz's theory of practical authority to a popular method of constitutional interpretation.

80478 U.S. 186 (1986).

81 Frank Michelman, Law's Republic, 97 YALE L.J. 1493, 1496 (1988).

82 See Hardwick, 478 U.S. at 190 ("This case does not require a judgment on whether laws against sodomy ... are wise or desirable.").

${ }^{83} \mathrm{Id}$. at 192.

${ }^{84}$ Id. at 192-93. 
sodomy is not encompassed within the core value sought to be protected), the Court could not rely on its own (or anyone else's) moral preferences to interpret the constitutional text as requiring the invalidation of the Georgia law. Whether the text itself might be vague enough to be susceptible to such an expansive reading had no bearing. ${ }^{85}$ Such is the exclusionary force of the framers' practical authority: the moral conclusions evident in the historical record exclude from the Court's reasoning any independent consideration of substantive values and provide the only permissible basis for the Court's interpretive decision-making. And such is the nature of practical authority as defined by Raz.

\section{JUSTIFyIng the Framers' Practical AUthority}

\section{A. Legitimate Practical Authority}

According to Raz, a practical authority is legitimate (an entity justifiably is accorded or claims to be a practical authority) if it "serves" its subjects. ${ }^{86}$ This "service conception" of authority is expressed by Raz's "Normal Justification Thesis": "[T]he normal way to establish that a person has authority over another person involves showing that the alleged subject is better likely to comply with reasons which apply to him (other than the alleged authoritative directives) if he accepts the directives of the alleged authority as authoritatively binding and tries to follow them, rather than by trying to follow the reasons which apply to him directly. ${ }^{87} \mathrm{~A}$ subject is served by a practical authority if obedience, rather than independent calculation, is more likely to yield action in accordance with the balance of antecedently existing first-order reasons. ${ }^{88}$ People are poor calculators of reasons for action. A practical authority is legitimate if, on the whole, it is a more superior calculator of first-order reasons than its subjects, solving the problem of frequent moral error. ${ }^{89}$

85 See id. at 194-96 (declining to expand the reach of the Due Process Clause); see also Robin L. West, The Authoritarian Impulse in Constitutional Law, 42 U. MIAMI L. REv. 531, 532 (1988) (describing the distinction made by the Supreme Court between constitutional issues and moral issues and calling the former "amoral").

${ }^{86}$ See RAZ, supra note 1 , at 55-56.

$87 \mathrm{Id}$. at 53 .

${ }^{88}$ See id. at 53-57.

${ }^{89}$ See id. at 53; Alexander, supra note 1, at 6-7. 


\section{The Obligations of Citizens}

Recall that according to Raz's Dependence Thesis legal authorities should promulgate rules that sum up the balance of antecedently existing first-order reasons that would apply to citizens in the absence of legal authority. ${ }^{90}$ If the lawmaker exhibits greater reason-calculating expertise than the citizen, and if the lawmaker adheres to the Dependence Thesis in its promulgation of laws, then the Normal Justification Thesis will necessarily be satisfied. By accepting the result of the lawmaker's (probably more accurate) calculation of the balance of reasons as a protected reason, and foregoing an attempt to run the calculation for himself, the citizen will be more likely to act in accordance with the balance of firstorder reasons applicable to him. As Raz insists, it is only when the Normal Justification Thesis is satisfied that the Preemptive Thesis applies.91 Only when the lawmaker is a better calculator of reasons than the citizen can it make any sense for the citizen to refrain from examining for himself his own reasons for action; only when the citizen is more prone to moral error than the lawmaker is the lawmaker's practical authority over the citizen legitimate.

A citizen's obligation to obey the law of a state is coextensive with the state's legitimate authority over that citizen. ${ }^{92}$ From this follows the most surprising aspect of the Normal Justification Thesis: there is no general obligation to obey the law. ${ }^{93}$ If a subject happens to be more of an expert in a given area than the legal authority and is therefore more likely than the legal authority to calculate correctly the balance of first-order reasons, then the lawgiver is not a legitimate practical authority for that subject over that area. The result is that "the extent of governmental authority varies from individual to individual, and is more limited than the authority governments claim for themselves in the case of most people. ${ }^{94}$

Raz recognizes that the service conception's narrow understanding of authority's legitimacy "invites a piecemeal approach to the questions of the authority of governments. ${ }^{\text {95 }}$ There will be many people in a multitude of situations with respect to whom the

${ }^{90}$ See supra notes $44-48$ and accompanying text.

${ }^{91}$ See RAZ, supra note 1, at 46.

92 See id. at 99-105.

${ }^{93}$ See RAZ, supra note 27, at 233-49.

$94 \mathrm{RAZ}$, supra note 1 , at 80.

${ }^{95} \mathrm{Id}$. 
lawmaker will not have better reason-calculating expertise and for whom the law therefore will not satisfy the requirements for legitimacy established by the Normal Justification Thesis. An example, offered by Raz, of a situation in which the law does not have a legitimate claim to practical authority is that of the auto mechanic whose expertise in the area of automobile design, function, and repair, combined with "an unimpeachable moral character, ${ }^{n 96}$ renders him exempt from an obligation to obey the law's commands regarding "the road worthiness of his car." ${ }^{\text {97 }}$ It is not that the law is necessarily unjust; it is just that the mechanic is apt "to do better if [he] refuse[s] to acknowledge the authority of this law. ${ }^{98}$ In this situation, the law's claim of authority is simply not justified. ${ }^{99}$

Despite the piecemeal legitimacy of legal authority offered by the Normal Justification Thesis, there are justifications of general applicability that support a practical authority's legitimacy. These justifications describe situations in which the legal authority will always be a better calculator of reasons than any individual citizen. For example, a central authority is necessary to solve coordination problems, such as getting everybody to drive on the same side of the road. In this situation there is no "right" answer. What matters is that everybody does the same thing. Since only a centralized practical authority can guarantee universal compliance, by giving protected reasons for coordinated action, law's claim of practical authority is legitimate in these situations. ${ }^{100}$

The "prisoners' dilemma" provides a second broad justification for legal authority. ${ }^{101}$ A prisoners' dilemma arises when each individual can benefit by acting self-interestedly, but overall benefit is maximized when everyone acts cooperatively. One individual's benefit is maximized by acting self-interestedly when all others act

96 Id. at 78.

$97 \mathrm{Id}$.

98 Id.

${ }^{99}$ For additional analyses of situations in which it would be irrational for an independent moral agent to defer to authority, see Regan, supra note 1, at 1030-31; Schauer, supra note 1, at 691-92; M.B.E. Smith, Is There a Prima Facie Obligation to Obey the Law?, 82 YALE L.J. 950 (1973).

${ }^{100}$ See RAZ, supra note 1, at 30, 49-50, 56; see also Leslie Green, Law, Legitimacy, and Consent, 62 S. CAL. L. REV. 795 (1989) [hereinafter Green, Legitimacy]; Leslie Green, Law, Coordination and the Common Good, 3 OXFORD J. LEGAL STUD. 299 (1983); Regan, supra note 1 , at 1024. But see Hurd, supra note 1, at 1632-35 (rejecting the need for new reasons to ensure universal compliance).

101 See RAZ, supra note 1, at 50-51. 
cooperatively and one's benefit is minimized by acting cooperatively while all others act self-interestedly. The non-optimal situation of everyone's acting self-interestedly leaves everyone worse off than if everyone acted cooperatively, but acting self-interestedly insures one against the worst-case scenario in which one is the only cooperative actor. Thus, each individual's most rational choice is to act selfinterestedly. ${ }^{102}$ In a prisoners' dilemma situation, "individually rational behavior is jointly inefficient because it leads to an outcome [(everyone's acting self-interestedly)] . . . which each prefers less than another [(everyone's acting cooperatively) $]$. . . that is available to them." 103 A central authority is needed to provide everyone with a sufficient reason to act cooperatively, so that no cooperating individual faces the risk of being the worst off. The law accomplishes this task by claiming practical authority over everybody, demanding cooperative action, and providing an exclusionary reason that bars consideration of the reasons not to cooperate. Since the overall best result is achieved by everyone's cooperation and since only the law's centralized authority will guarantee full cooperation, law's claim to practical authority is legitimate when prisoners' dilemmas arise. ${ }^{104}$ Nevertheless, neither prisoners' dilemma situations nor coordination problems provide a general justification for law's authority, such that all citizens have a general obligation to obey all (or even most) of the time.

In addition to the Normal Justification Thesis, Raz offers "consent" and "respect for the law" as two possible secondary justifications that can establish the legitimacy of a state's claim of practical authority. To the extent that an individual legitimately consents to governmental authority, or has legitimate respect for the state's laws, then that individual has additional secondary reasons to treat the state as a legitimate practical authority. These justifications are supplemental to the service conception of authority, however. The Normal Justification Thesis remains the primary means by which an authority is legitimated because the two secondary reasons offer no independent justification for law's claim

102 See R. DUNCAN LUCE \& HOWARD RAIFFA, GAMES AND DECISIONS 94-102 (1957) (discussing the prisoners' dilemma in terms of game theory); ROY SORENSON, BLINDSPOTS 4-7 (1988) (same).

103 ROBERT NOZICK, ANARCHY, STATE, AND UTOPIA 124 (1974).

104 See RAZ, supra note 1 , at 50-51, 56. 
of practical authority apart from the Normal Justification Thesis. ${ }^{105}$

Raz acknowledges the force of consent in providing a citizen with an obligation to treat his government as having legitimate practical authority. ${ }^{106} \mathrm{He}$ accepts as legitimate only actual consent that is both voluntary and fully informed, however. ${ }^{107}$ Furthermore, even if consent is freely and knowingly given the citizen is bound by that consent only if it satisfies the condition that "[a]cting on the government's directives will promote one's success in following right reason." ${ }^{108}$ As Raz points out, consent is binding only if the authority itself satisfies the conditions "establishing the legitimacy of an authority independently of consent."109 Thus, consent is valid only when the Normal Justification Thesis is satisfied by the authority to whom consent is given. It is therefore difficult to see how consent does any work at all in justifying a government's claim to authority. Certainly a consenting citizen has greater incentive to obey legitimate, authoritative dictates of the legal authority than a nonconsenting citizen. ${ }^{110}$ But the presence of that consent is neither a necessary nor a sufficient condition for the law's legitimacy. ${ }^{111}$ For Raz, the value of consent seems to be merely instrumental. ${ }^{112}$

Raz also develops a theory about how respect for the law can be manifested by a citizen's self-expression. Such a person has an obligation to obey the laws of the state so long as: the legal system is worthy of respect; the community recognizes respect for the law as an "appropriate and desirable expression of identification with the community;"113 and this form of expression is inculcated as part of the general process of socialization in the community. ${ }^{114}$

105 See id. at 88-101.

${ }^{106}$ See id. at 80-94.

${ }^{107}$ See id. at 81, 88-90.

${ }^{108}$ Green, Legitimacy, supra note 100 , at 810 . This is just a restatement of the Normal Justification Thesis. See id. at 810 n.33.

${ }^{109} \mathrm{RAZ}$, supra note 1 , at 21-22.

110 See id. at 89-90. Such incentive is by no means always a good thing, as "[i]t may mislead people into obeying the law where, but for consent, it would have been clear to them that it is better to disobey. An extreme example of this kind of distortion is provided by the scruples of many German generals about breaking their oath of loyalty." Id. at 90.

111 See id. at 88.

112 But see id. at 92 ("Noninstrumental validations of consent are ... limited to consent to the authority of a reasonably just government.").

113 Green, Legitimacy, supra note 100, at 815 .

114 See RAZ, supra note 1, at 94-99. 
Raz points out that just because identification with one's (reasonably just) community is a good thing and accepting the state's authority is a good way of expressing that identification, it does not follow that one has an obligation to accept the state's authority. ${ }^{115}$ Obligation only follows from the individual's actual, unself-conscious acceptance of authority. ${ }^{116}$

Raz distinguishes respect for the law from consent. Consent must be a conscious, willful decision of the mind, ${ }^{117}$ while respect is a general mindset that evolves over time as "the product of a gradual process as lengthy as the process of acquiring a sense of belonging to a community and identifying with it."118 Yet the fact that such respect is only a good thing in a "reasonably just"119 society implies that respect for the law, like consent, has obligatory force only when the state's authority is otherwise legitimate. Again, the test for legitimacy may be the requirements of the Normal Justification Thesis. ${ }^{120}$

Despite the operation of consent and respect for law to create or reinforce obligations to obey the law there is still, under Raz's theory, no general obligation for citizens to obey the law. Raz concludes that there is no prima facie obligation to obey the law that transcends the bounds of a state's legitimate authority as defined by the Normal Justification Thesis. ${ }^{121}$

\section{The Obligations of Judges}

Although the law has no legitimate claim to practical authority over all citizens all of the time, it does appear that there is a broader obligation to obey for judges. In addition to the Normal Justification Thesis, there are other reasons why judges should treat the laws of a legal system of which they are a part as the binding commands of a legitimate practical authority. ${ }^{122}$ First, a judge's

115 See id. at 99.

116 See id.

117 See id. at 81.

$118 \mathrm{Id}$. at 98 .

119 Id. at 99 .

${ }^{120}$ The notion of a relationship between a society's being "reasonably just" and the Normal Justification Thesis is explored in greater detail infra notes 141-43 and accompanying text.

121 See RAZ, supra note 1, at 101-02.

122 Note once again that these reasons only apply in a legal system that is "reasonably just." This depends, to some extent, on the Normal Justification Thesis being satisfied. See infra notes 141-43 and accompanying text. 
adherence to the law yields systemic benefits that do not necessarily follow from citizens' obedience. ${ }^{123}$ Among these benefits are the rule of law virtues discussed earlier, ${ }^{124}$ including liberty, which is served by judges applying the law in a predictable and consistent manner. ${ }^{125}$ Predictability enhances liberty by increasing the number of options available to individuals. In the absence of predictability people will avoid choosing certain options because of the fear of potential reprisal. ${ }^{126}$ Since this kind of predictability is achievable only if judges defer to the authority of law without engaging in their own moral balancing, liberty enhancement gives judges a "reason to regard the laws of [their] system as possessing legitimate authority and thus as obligating" them in their role as judges. ${ }^{127}$

Second, Raz implies that we all have a moral obligation to support just institutions. ${ }^{128}$ To the extent that disobedience undermines the state's authority by setting a bad example, disobedience in a just legal system is contrary to this moral obligation. Because disobedience by citizens typically does not engender general lawlessness, Raz thinks it a "melodramatic exaggeration" to suppose that every disobedient act endangers the state or law and order. ${ }^{129}$ But given that lawless behavior by judges acting in their official capacity would very likely discourage citizens from viewing the law as worthy of obedience, it would seem that "judges have a special obligation to obey the laws as they judge." 130

Finally, judges, unlike native-born citizens, usually take an oath of office in which they swear to uphold the laws of the state. When judges take oaths voluntarily, such oaths are equivalent to promises. They are examples of what Raz refers to as the exercise of the normative power to create voluntary obligations. ${ }^{131}$ People have

${ }^{123}$ See Heidi M. Hurd, Justifiably Punishing the Justified 43-115 (1992) (unpublished manuscript, on file with the author) (addressing the systemic benefits to be derived from judicial obedience).

124 See supra note 48 and accompanying text.

${ }^{125}$ See Moore, supra note 1 , at 836.

126 See id.

${ }^{127} \mathrm{Id}$.

128 See RAZ, supra note 1, at 101; RAZ, supra note 27, at 237-42, 245-49.

${ }^{129} \mathrm{RAZ}$, supra note 1 , at 102.

${ }^{130}$ Moore, supra note 1 , at 836 . Here, too, this obligation of the judge depends upon the existence of a reasonably just legal system. See id.; infra text accompanying notes 141-43.

${ }^{131}$ See Joseph Raz, Promises and Obligations, in LAW, MORALITY AND SOCIETY: EsSAYS IN HONOUR OF H.L.A. HART 210 (P.M.S. Hacker \& Joseph Raz eds., 1977); Joseph Raz, Promises in Morality and Law, 95 HARV. L. REV. 916, 927-33 (1982) (book 
the capacity to create new reasons for action that morally obligate, and making a promise "transforms one's reasons, creating a new reason not previously there. ${ }^{n 132}$ This exercise of a normative power is the functional equivalent of a person at one moment in time exercising practical authority over himself at some later point in time. The judge's exercise of his normative powers, by taking an oath of office, obligates him to apply the law and to exclude from consideration otherwise countervailing factors, such as his own superior reason-calculating ability. As with consent, however, the validity of promises is limited by the legitimacy (perhaps, in the case of judicial oaths, according to the Normal Justification Thesis) of what is promised. ${ }^{138}$

In addition to the above three reasons, the Normal Justification Thesis obligates judges beyond the basic situation in which the legal authority is a better calculator of the balance of first-order reasons. Because the judge is the agent that applies the law, the Normal Justification Thesis obligates the judge to a greater degree than it does citizens.

If the law is a legitimate practical authority for the citizen, the judge is obligated to apply the law even in cases where the judge calculates reasons better than the lawmaking authority. Imagine a judge who is an expert auto mechanic and a scrupulously moral person. The laws determining an automobile's road worthiness may not be authoritative for this judge, because of his superior technical expertise. ${ }^{194}$ Nevertheless, when a citizen unskilled in the intricacies of automobile design comes before the judge in a case in which such laws are applicable, the judge is bound to apply these laws to this citizen. This is so for two reasons. First, if, as Raz asserts, the judge's role is to apply the legitimate laws of the legal system, and these laws are, according to the Normal Justification Thesis, legitimate for this citizen, then his role as a judge is to apply the laws. ${ }^{135}$ Second, if we define "guilty" as having violated one's obligation to obey the law and "innocent" as not having done so, and if we further adopt what Rolf Sartorius has dubbed the "Reflection Principle," according to which all and only the guilty

review).

132 RAz, supra note 1 , at 387.

${ }^{133}$ See id. at 388; see also id. at 82, 173 (discussing promises that are not valid, including those concerning the actions of other persons and those considered immoral).

${ }^{134}$ See supra notes 96-99 and accompanying text.

${ }^{135}$ See RAZ, supra note 27, at 105-15. 
should be punished, ${ }^{136}$ then it follows that the judge must respect the legitimate authority of the law for the citizen because it is that legitimacy that determines the extent of the citizen's obligation to obey. ${ }^{187}$

Even in cases where the law is not a legitimate authority for either citizen or judge, if the citizen believes, albeit incorrectly, that he has an obligation to obey (because of an incorrect belief that the lawmaker satisfies the Normal Justification Thesis and the law is legitimately binding), then the judge must honor that citizen's expectations. For example, imagine that both judge and citizen are expert auto mechanics. The citizen mechanic is unaware, however, that he is better than the legal authorities at calculating first-order reasons applicable to road worthiness. The citizen then wrongly believes that he is obligated to treat the road worthiness laws as binding authority; he believes that they give him protected reasons for action.

The judge might then be faced with one of four scenarios: (1) the citizen obeyed the road worthiness laws, and did the right thing by not driving his old jalopy, which belongs in a junkyard; (2) the citizen obeyed the road worthiness laws, and did the wrong thing by driving his old jalopy, which belongs in the junkyard, although the law allows it to be driven; (3) the citizen violated the road worthiness laws, and did the right thing by driving his old jalopy, which is prohibited by law from being driven, although it presents no hazard; or (4) the citizen violated the road worthiness laws, and did the wrong thing by driving his old jalopy, which belongs in the junkyard and is prohibited by law from being driven.

Of these scenarios only (3) is problematic. In (1) and (2), respect for the citizen's liberty (by honoring his expectations about the law), as well as a sense of fairness, require the judge to enforce the road worthiness laws by pronouncing the citizen "innocent." 138 In (4), the citizen has violated a law he believes to be

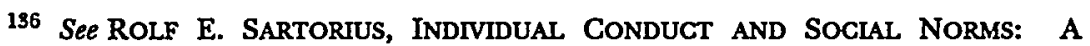
UTILTTARIAN ACCOUNT OF SOCIAL UNION AND THE RULE OF LAW 56-57 (1975). Sartorius, along with Larry Alexander, rejects the reflection principle. See id.; Alexander, supra note 1 , at $10 \& \mathbf{n} .8$.

137 See supra note 92 and accompanying text; RAZ, supra note 1, at 99-105.

138 On the definitions of "innocent" and "guilty" in these hypotheticals, see supra text accompanying note 136. Another way of looking at these situations is to recognize that the citizen must have the support of the person acting the "role" of judge to successfully carry out his "role" as citizen. The citizen depends on the judge to enforce the law, even if the law is wrong. For a discussion of the interrelationship of roles in a law-governed society, see MORTIMER R. KADISH \& SANFORD H. KADISH, 
legitimate and has gotten it wrong to boot. There does not seem to be any reason for the judge to refrain from enforcing the law by pronouncing him "guilty." In (3), however, the judge is presented with a problem. As in (4), honoring the citizen's expectations weighs in favor of a "guilty" verdict. But these laws are not legitimately authoritative for the citizen, even though he believes them to be. Disregarding any problems about setting a bad example, the citizen has not done anything "wrong," and the judge knows it, since he, like the citizen, has more automotive expertise than the lawmakers. Scenario (3) can only be resolved by balancing the value of honoring expectations, and the liberty enhancement thereby served, against the fact that the citizen did the right thing, all things considered, by disregarding a law that is not even legitimately binding on him. ${ }^{139}$ In the other three scenarios, the judge is bound to honor the citizen's expectations about the laws' authoritativeness, even though the laws satisfy the Normal Justification Thesis for neither the citizen nor the judge. ${ }^{140}$

The Normal Justification Thesis helps determine the extent of the judge's obligation to obey the law in one more way. A reason for obligation is conditioned on the relevant legal system being "reasonably just" in several instances previously described: respect for the law, ${ }^{141}$ the duty to uphold just systems, ${ }^{142}$ and the judge's duty to serve the rule of law virtues. ${ }^{143}$ The question that necessarily arises is how to determine whether a society is reason-

DISCRETION TO DISOBEY 17-18 (1973).

${ }^{199}$ Perhaps the tension can be resolved by an appeal to the proper relationship between the respective roles of citizen and judge. See supra note 138 . From this perspective, the disobedience of the citizen should yield a guilty verdict, regardless of the merits of his action because that is the only outcome that properly respects the roles of both citizen (to obey the law) and judge (to enforce the law). See KADISH \& KADISH, supra note 138, at 17-18. But of. id. at 29-39 (discussing when departures in roles are justified).

140 Scenario (2) can also be problematic in a radically unjust society. If citizens know that they will never be punished for committing atrocities if they can claim a mantle of "lawfulness," then there is always the danger of spreading evil. This danger does not mean that the judge within the evil-promoting legal system is free to punish the law-abiding evildoer within the system of evil laws. Rather, in order to do justice, the judge must step out of his role as judge; then he can pursue justice in his private capacity as an independent moral agent. See JOHN H. ELY, DEMOCRACY AND DISTRUST: A THEORY OF JUDICIAL REVIEW 182-83 (1980); J. Clifford Wallace, The Jurisprudence of Judicial Restraint: A Retum to the Moorings, 50 GEO. WASH. L. REV. 1, 7 (1981).

141 See supra notes $113-16$ and accompanying text.

142 See supra notes $128-30$ and accompanying text.

143 See supra notes $122-27$ and accompanying text. 
ably just. Raz does not directly address this question. There are at least two possible approaches to the issue. One is to examine the procedural aspects of the system and ask whether the system exhibits fairness in adjudication. An alternative is to focus on the substantive justice of the regime's laws. In the latter approach, a reasonable method for measuring a system's justice would involve use of the service conception of authority. If a legal system satisfies the Normal Justification Thesis for a reasonable percentage of its citizens, then the system is reasonably just. That is, if a system's lawmaker adheres to the Dependence Thesis in promulgating laws, and exhibits, overall, greater reason-calculating capacity than its citizens, it is fair to characterize the system as reasonably just.

In summary, the service conception of law's legitimacy does not provide citizens with a general obligation to obey the law. The combination of the Normal Justification Thesis and the special concerns inherent in the judge's role, however, create a broader obligation for the judge to treat the laws of the legal system as bindingly authoritative. To a much greater degree than the citizen, the judge is preempted from further investigation of the values that underlie the laws and is precluded from considering relevant concerns that might weigh against following the law in a given situation. 144

Nevertheless, Raz contends that under his theory of authority's legitimacy there is still no general obligation of obedience even for the judges within a legal system since the "additional reasons for obeying the law which apply to judges, at least in reasonably just societies ... [do not] amount to a binding moral obligation in all cases." ${ }^{\text {145 }}$ The piecemeal nature of the obligation to obey holds for judges as well, albeit to a lesser extent than for citizens.

\section{B. The Legitimacy of Originalism}

I have explained how Raz's arguments for the legitimacy of legal authority depend on a lawmaker's possessing greater expertise in balancing first-order reasons than the law's subjects. How then would the service conception of authority apply to the framers? Under the Normal Justification Thesis, are originalists justified in

144 Compare Schauer, supra note 1, at 692 (arguing in favor of role-relative reasons for action applicable to judges) with Hurd, supra note 123 (disputing the existence of role-relative reasons for judicial action).

${ }^{145}$ Raz, supra note 51 , at 1170 n.28. 
according practical authority to the framers over the judge's interpretive enterprise? There are at least two ways in which the framers might satisfy the thesis. First, the drafters of the Constitution and its amendments might have been moral geniuses whose understanding of democratic government far exceeds that of any judge today. Alternatively, the American process of constitutionmaking might be such that only by adhering to the moral conclusions arrived at through that process are the best possible results guaranteed. After briefly examining these two propositions, I consider whether originalists would accept Raz's thesis of a legal authority's legitimacy. After determining that they would not, I am left with an intriguing situation: originalists adopt Raz's model of how authority works, ${ }^{146}$ yet they reject his explanation of when an entity is justified in claiming such authority. I then examine consent and judicial restraint as alternative grounds for the legitimacy of the framers' authority before concluding that originalists cannot justify granting Razian practical authority to the framers.

\section{The Framers and the Normal Justification Thesis}

Whatever their qualities and their legacy, it is difficult to believe that the framers were moral geniuses. Yet at least one scholar critical of strict originalism, David Richards, seems to accept the proposition that the framers were best situated to make a democratic Constitution. He writes: "What makes the American Founders so remarkable is the way in which ... [they] combined extensive practical experience as politicians working in democratic institutions with an astonishing grasp of the political philosophy and political science of an enlightened age." 147 To Richards, the framers "were great lawyers, political leaders, and intellectuals of the first rank," such that " $[t]$ heory and practice were . . . powerfully interwoven in one of history's greatest demonstrations of the deliberative powers of the democratic reason of a free people." 148 Richards believes that "constitutional conservativism" can be justified by articulating "for Americans today the quality of the moral and intellectual achievement of their remarkable Founders and demand[ing] that this most precious heritage be conserved with the same quality of

\footnotetext{
${ }^{146}$ See supra notes 54-85 and accompanying text.

147 Richards, supra note 70 , at 1397.

${ }^{148}$ Id. at $1397-98$.
} 
intellectual and moral depth and rigor with which it was invented."149 This justification for according legitimate practical authority to the framers seems to be based on the idea that the framers were the right men in the right place at the right time. But however admirable they may be, the small group of aristocrats who convened in Philadelphia over 200 years ago were not in an intellectually and morally superior position to analyze and sum up the reasons for action applicable in modern society. Furthermore, no originalist has advanced the idea that the innate superiority of the framers is a justification for looking to their intentions as the authoritative source of constitutional meaning.

The sense that the drafting of the Constitution was an ideal process is another possible reason for concluding that the framers' intentions better strike the balance of first-order reasons than do a judge's own consideration of the relevant factors. The problem with this argument is that the only output of the constitutional convention and the ratifying conventions was the Constitution itself, not the intentions of the participants in the process. "Nothing but the text itself was adopted by the people," according to Justice Story. ${ }^{150}$ While it is possible to argue in favor of the text's authority based on the quality of the process that produced it, no such argument is possible with regard to framers' intent.

It thus appears difficult to construct a plausible argument, based on the Normal Justification Thesis, for according practical authority to the framers' intentions. This difficulty is moot, however, since originalists would be unlikely to accept Raz's account of when authority is justified, at least as applied to the authority of the framers over the judge. There are two reasons why this is so. First, originalists would reject the piecemeal nature of the obligation to obey imposed by the Normal Justification Thesis. ${ }^{151}$ Regardless of any superiority in reason-balancing capacity a judge may have, originalists demand that the judge always treat the intentions of the framers as providing binding, protected reasons for interpreting the text in accordance with those intentions. ${ }^{152}$ Any justification of framers' authority that has the potential of excusing the judge from

149 Id. at $1399-1400$.

1501 JOSEPH STORY, COMMENTARIES ON THE CONSTITUTION OF THE UNITED STATES 300 (Boston, Little Brown 4th ed. 1873).

${ }_{151}$ See supra notes 93-95, 145 and accompanying text.

152 See supra note 78 and accompanying text. 
the deferential posture favored by originalists is therefore unacceptable.

Second, originalists do not think that the judge's obligation to give binding effect to the intentions of the framers has anything to do with who is more likely to get the balance of reasons right. For originalists, the meaning of the Constitution's text is the intent of the framers. "This is the essence of communication. It is for the writer to explain what his words mean .... ${ }^{n 153}$ Originalists hold to an "intentionalist" theory of meaning. They believe that "[i]t would ... be a contradiction in terms ${ }^{\text {154 }}$ to speak of meaning apart from authorial intentions and that to "assign a meaning different from the one intended by the original authors ... merely substitutes some other hypothetical author for the historical ones." 155 Because of the definitional force ascribed by originalists to the intentions of the framers, they would reject any theory of justification, such as Raz's, that might provide the judge with the freedom to look elsewhere for interpretive meaning.

The importance (if any) of authorial intent in textual interpretation is not a settled issue, however. ${ }^{156}$ Scholars in many interpretive disciplines, including law, literature, religion, art, and music, have for some time been engaged in a heated debate over the relevance of intent. ${ }^{157}$ There have been significant attempts to set forth an intentionalist theory of meaning. ${ }^{158}$ But such theories

153 Raoul Berger, Originalist Theories of Constitutional Interpretation, 73 CORNELL L. REV. 350, 353 (1988).

154 Kay, supra note 60, at 231.

155 Id.; see also ELY, supra note 140 , at 3.

156 See, e.g., DON HERzoG, HAPPY SLAVES: A CRITIQUe OF CONSENT THEORY 25-27 (1989) (addressing the controversy regarding interpretation based on authorial intent and rejecting the view that "history is valuable because it enables us to recapture the author's intentions and so the meaning of his text" because authors' "audiences will understand their texts in ways that have nothing to do with their intentions").

${ }^{157}$ See, e.g., INTERPRETING LAW AND LITERATURE at x-xii (Sanford Levinson \& Steven Mailloux eds., 1988) (discussing current controversies in modern interpretive theory); Sanford Levinson \& J.M. Balkin, Law, Music, and Other Pefforming Arts, 139 U. PA. L. REV. 1597, 1597-614, 1654-58 (1991) (discussing the relevance to legal interpretation of current interpretive disputes within music, literature, and other arts); see also Daniel A. Farber, The Originalism Debate: A Guide for the Perplexed, 49 OHo ST. L.J. 1085, 1101 (1989) (noting that "it is not clear that the meaning even of ordinary texts is to be located in the author's intent as opposed to the reader's understanding" and that "[ $t]$ heories of interpretation are presently the subject of hot dispute among philosophers and literary theorists").

${ }^{158}$ The most plausible intentionalist theory of meaning is that propounded by Paul Grice, whose only book, STUDIES IN THE WAY OF WORDS (1989), contains his 1967 William James Lectures. The most relevant chapter is "Utterer's Meaning and 
have been subjected to severe criticism on both rational ${ }^{159}$ and moral grounds. ${ }^{160}$ Perhaps the most fundamental criticism of the application of intentionalist theories of meaning is that any attempt to close off the interpretive enterprise by appeal to a final interpretive authority is doomed to failure because of an unavoidable infinite regression, since the authoritative interpreter must itself be interpreted. ${ }^{161}$

\section{The Argument from Consent}

Given originalism's rejection of Raz's explanation for the legitimacy of the framers' interpretive authority, the originalist is faced with the predicament of having to provide a non-Razian justification for treating the framers as endowed with Razian practical authority. One possibility is a social contract or consentbased theory of legitimacy. As demonstrated previously, Raz's definition of consent provides a legitimate basis for practical authority only when the Normal Justification Thesis is satisfied. ${ }^{162}$ But as this Comment has also shown, the limited nature of authority's legitimacy implied in that thesis makes it unacceptable to originalists preoccupied with judicial restraint. ${ }^{163}$ Any originalist appeal to consent must rely on a less rigorous notion of valid consent than that advocated by Raz.

Intentions." See also H.P. Grice, Meaning, in READINGS IN THE PHILOSOPHY OF LANGUAGE 436 (Jay F. Rosenberg \& Charles Travis eds., 1971).

159 See Brest, supra note 54, at 209-24.

160 See Moore, supra note 48, at 352-58. tion:

161 This objection is well stated by Herzog in a discussion of scriptural interpreta-

[Some would claim that i]f we have doubts about the meaning of some passage of Scripture, we should accept the authoritative judgment of the church.

From one point of view, this solution simply begs the question. After all, does the church have privileged access to the meaning of the text? ... And anyway don't we have to interpret their judgments when we receive them? And wouldn't asking the church for instructions on interpreting its previous judgments land us in a vicious regress? To be cogent, interpretive disputes have to remain open, not be closed by some authoritative judgment. Imposing an authoritative judgment isn't another approach to interpretation; it's an attempt to escape the messy business of interpretation altogether.

HeRzoG, supra note 156 , at $142-43$ (footnote omitted).

162 See supra notes $105-09$ and accompanying text.

${ }^{163}$ See supra notes 151-52 and accompanying text. 
There are four possible consent-based sources of the framers' authority: actual consent, historical consent, implied consent, and hypothetical consent. ${ }^{164}$ Actual consent is impossible to establish; ${ }^{165}$ there is certainly nothing in our history that indicates that any significant portion of the American populace has given free, voluntary consent to the interpretive authority of the framers. ${ }^{166}$. Historical consent is, "of course, ... very implausible," ${ }^{167}$ and is therefore incoherent as a basis for the framers' authority over the present generation of Americans. ${ }^{168}$ Implied (or tacit) consent cannot be derived from the fact that no one has revolted against the authoritative regime of framers' intent or amended it out of existence, in part because a failure to try to change things does not necessarily betoken consent ${ }^{169}$ and in part because there has been no such regime about which to complain. Until quite recently the notion that the framers' intentions act as binding authority on judges interpreting the Constitution has had little currency with either the Justices of the Supreme Court ${ }^{170}$ or the academy. ${ }^{171}$

${ }^{164}$ An extended foray into the realm of consent theory is beyond the scope of this Comment. For analysis and criticism of consent theory in general, see HERZOG, supra note 156. For discussions of the relationship between consent theory and political authority, see RAZ, supra note 1, at 21-22, 80-94; A. JOHN SIMMONS, MORAL PRINCIPLES AND POLITICAL OBLIGATIONS 79 (1979); Green, Legitimacy, supra note 100.

165 See, e.g., RAZ, supra note 1, at 88 (noting "the well-known problem that most citizens in any given society have not consented to the authority of their government"); SIMMONS, supra note 164, at 79 ("Since the earliest consent theories it has of course been recognized that 'express consent' is not a suitably general ground for political obligation. The paucity of express consenters is painfully apparent.").

${ }^{166}$ Larry Simon estimates that approximately $2 \frac{1 / 2}{2} \%$ of the population participated in the ratification process. See Larry G. Simon, The Authority of the Framers of The Constitution: Can Originalist Interpretation be Justified?, 73 CAL. L. REV. 1482, 1498 n.44 (1985).

${ }^{167}$ Simmons, supra note 164 , at 60 . Simmons emphasizes that "only in very special circumstances can the consent of one individual bind some other individual (even if this latter individual is a descendant of the former)." Id.; see also IMMANUEL KANT, ON THE OLD SAW 65, 69-70 John R. Silber ed. \& E.B. Ashton trans., University of Pennsylvania Press 1974) (1793); JOHN LOCKE, SECOND TREATISE OF GOVERNMENT $\S \S 112-18$ (C.B. Macpherson ed., Hacket Publishing 1980) (1690).

${ }_{168}$ See Moore, supra note 2, at 120.

169 See, e.g., SIMMONS, supra note 164, at 79-100 (emphasizing that failure to dissent is only rarely constitutive of consent, and discussing Locke's analysis of the failure of implied consent); Brest, supra note 54, at 226 (noting that "[a]cquiescence is not the same as 'consent,' which must be informed and knowingly and freely given"); see also J.F.M. Hunter, The Logic of Social Contracts, DIALOGUE, June 1966, at 31 (discussing the prerequisites for implied consent).

170 As Justice Scalia mournfully concedes:

[O]riginalism is not, and perhaps [has] never been, the sole method of constitutional exegesis. It would be hard to count on the fingers of both 
"[T]he practice of supplementing and derogating from the text and original understanding is itself part of our constitutional tradition."172 Hypothetical consent is based on asking about what sort of authority rational, self-interested persons would consent to if given the choice. ${ }^{173}$ Unfortunately, since answering this question requires a moral theory about what sort of system of government is deserving of consent, ${ }^{174}$ theories based on hypothetical consent collapse into theories of substantive morality and rational action $^{175}$ which, as noted above, grant "authority" only to the extent that the framers' will is consistent with morality. ${ }^{176}$ No social contract theory provides a legitimate basis for according binding practical authority to the framers' intentions. ${ }^{177}$

hands and the toes of both feet, yea, even on the hairs of one's youthful head, the opinions that have in fact been rendered not on the basis of what the Constitution originally meant, but on the basis of what the judges currently thought it desirable for it to mean.

Antonin Scalia, Originalism: The Lesser Evil, 57 U. CIN. L. REv. 849, 852 (1989).

${ }^{171}$ See, e.g., id. at 853 (noting that "many prominent and respected commentators reject the original meaning of the Constitution as an authoritative guiden ).

172 Brest, supra note 54 , at 225 .

${ }^{173}$ The most well-known formulation of a theory of political legitimacy based on hypothetical consent is found in JOFN RAWLS, A THEORY OF JUSTICE (1971), in which Rawls posits that the just society is that which would be consented to by social contractors in an "original position" of ignorance about what their place in society is destined to be. See id. at 136-42.

174 See id. passim.

175 See HERZOG, supra note 156, at 4, 34-35; SIMMONS, supra note 164, at 144.

176 See supra note 8 and accompanying text; infra note 190 and accompanying text.

177 See, e.g., TUSHNET, supra note 68, at 23 (asserting that "[ $t$ ]reating the Constitution like a contract . . . is difficult to defend cogently"); see also Simon, supra note 166, at 1495-519 (denying the consent-based justification of originalism).

According to John Simmons, "[t]he challenge . . . remain[s] open to the modernday consent theorist to show us how government by consent can be made a reality." SIMMONS, supra note 164, at 100. Owen Fiss argues that consent is never a proper measure of the legitimacy of any political institution. "The legitimacy of particular institutions, such as courts, depends not on the consent-implied or otherwise-of the people, but rather on their competence, on the special contribution they make to the quality of our social life." Owen M. Fiss, The Supreme Court, 1979 Term: Foreword: The Forms of Justice, 93 HARV. L. REV. 1, 38 (1979). Professor Fiss's description of the desiderata of institutional legitimacy is consistent with the underlying assumptions of Raz's service conception of legitimate authority. See supra notes 86-89 and accompanying text. 


\section{The Argument from Democracy}

The most common justification given by originalists for their interpretive theory is democracy. The argument is as follows: Democracy means majority rule and some protection for individual rights. Judges protect the individual from majority intrusion. In order to be democratically legitimate, unelected judges must be "constrained" by law, such as the Constitution. But judges must interpret the Constitution in order to apply it to individual cases. They may be insufficiently restrained. Thus, we turn to an originalist theory of interpretation because it is the only interpretive methodology that sufficiently constrains judges and preserves majoritarianism. ${ }^{178}$

Justice Scalia articulates such a defense of originalism: "[T]he main danger in judicial interpretation of the Constitution-or, for that matter, in judicial interpretation of any law-is that the judges will mistake their own predilections for the law."179 Unlike competing theories of interpretation, originalism "does not aggravate the principal weakness of the system, for it establishes a historical criterion that is conceptually quite separate from the preferences of the judge himself." 180

Such reasoning is reminiscent of Thomas Hobbes. ${ }^{181}$ Hobbes insisted that the interpretive enterprise allows judges too much freedom, posing a potential threat to the absolute authority of the Sovereign. To minimize this threat, Hobbes declared that the only true meaning of any law is to be found in the intentions of the Sovereign, whose will is the source of all laws. By limiting interpretation to discovering the will of the Sovereign, Hobbes would prevent judges from exercising their own authority in a way threatening to the Sovereign. ${ }^{182}$ Hobbes was concerned with protecting the authority of the King from meddling judges; originalists make an analogous argument on behalf of the framers. Larry Simon calls this argument a "residualist" justification for originalism; it is based not so much on the virtues of originalism as on the shortcomings of other interpretive methods. ${ }^{183}$ This

${ }^{178}$ See Bork, supra note 59, at 43-52; Berger, supra note 54, at 4; ELY, supra note 140, at 4-9; Farber, supra note 157, at 1097-103; TUSHNET, supra note 68, at 26-27.

${ }^{179}$ Scalia, supra note 170 , at 863 .

${ }^{180} I d$. at 864 .

181 See ThOMAS HobBES, LEVIATHAN 218-19 (Bobbs-Merrill 1958) (1651).

182 See id.

183 See Simon, supra note 166, at 1495; see also Scalia, supra note 170 , at 863-64 
characterization is reinforced by Justice Scalia's choice of the title "The Lesser Evil" for his defense of originalism. ${ }^{184}$ According to originalists, other methods allow judges too much discretion. ${ }^{185}$

At first, this argument from democracy has appeal. Liberty, it is argued, is intrinsically valuable. Democracy is the "extension of liberty into the realm of social decisionmaking." 186 Thus democracy, like liberty, is intrinsically valuable. To ensure adequate protection of this fundamental value judges should "shrink from abrogating legislative decisions and ... look for ways to uphold legislation rather than to strike it down." ${ }^{187}$ This argument demonstrates that restraint is an important characteristic of the judicial role in a democratic society. From the perspective of legitimating the practical authority of the framers, however, this argument says nothing about why it is the framers who should be accorded the authoritative status originalism demands. ${ }^{188}$ It is one thing to argue that judges should carefully consider the important value of democracy before rejecting an attitude of judicial restraint. It is another thing to say that judges must therefore abdicate their capacity as independent moral agents in favor of unquestioning adherence to the intentions of the Constitution's long-dead authors, whose intentions were never even voted on by a democratic majority. ${ }^{189}$

The argument from democracy, while supportive of judicial restraint, says nothing about the legitimacy of deference to framers' intent and fails as a justification for the practical authority of the framers. It is similarly unhelpful to claim that the framers' authority derives from the congruency of their intentions with the dictates of substantive morality. Such an argument grants the framers no authority at all, since it recognizes the authoritative force of morality, and supports acceding to the framers' will only to the extent that their will coheres with morality's requirements. ${ }^{190}$

(concluding that despite its shortcomings, originalism is better than nonoriginalism because it avoids granting judges the excessive interpretive freedom characteristic of nonoriginalism).

184 See Scalia, supra note 170.

185 See id. at 854,863 .

186 Wallace, supra note 140 , at 5.

187 Id.

188 As noted earlier, their status as authors of the text does not uncontroversially confer upon the framers any special authority over the text's meaning. See supra notes 156-61 and accompanying text.

${ }^{189}$ See supra notes 150,166 and accompanying text.

${ }^{190}$ See Moore, supra note 2, at 118. 


\section{CONCLUSION}

My stated intention ${ }^{191}$ has been to explore the consequences of examining originalism in the light of Raz's theory of practical authority. At first, it appeared that $\operatorname{Raz}$ and the originalist share much common ground; both insist on a model of authority demanding obedience without questioning the reasons therefor. ${ }^{192}$ On closer examination, however, it seems that $\mathrm{Raz}$ and the originalist are only incidentally similar in their views of authority. When we turn from an examination of how authority functions to considerations of when and why authority is legitimate, the similarities are shown to be for the most part illusory. This Comment has explained that under Raz's service conception theory of authority's legitimacy it is highly unlikely that the framers' authority could satisfy the requirements of the Normal Justification Thesis. In any event, originalists would reject Raz's thesis because it provides judges with an insufficiently broad obligation to obey. I have also argued that even apart from the service conception of authority originalists can offer no coherent, non-Razian justification for the framers' practical authority over the judge's interpretive enterprise. There is no rational basis for the judge unquestioningly to substitute the value choices of the framers for his own when deciding how to interpret and apply the Constitution in a particular case.

This analysis does not imply, however, that judges are unconstrained. As noted previously, any theory of adjudication within a democratic society must weight heavily the intrinsic value of democracy. ${ }^{193}$ When examining the validity of a democratically enacted statute by applying ambiguous constitutional text, the judge must consider the possible harm that might result to democratic values in selecting among possible interpretations. ${ }^{194}$ But a vision of democracy consisting of pure majoritarianism is overly simplified and controversial. Thomas Nagel argued:

Majority rule is based, as Professor Ely points out, on a certain conception of equality. Each member of a society is entitled to have his preferences count the same as anyone else's ....

191 No irony intended.

192 See supra notes 72-85 and accompanying text.

193 See supra notes $140-89$ and accompanying text.

194 See Wallace, supra note 140 , at 5. 
But the acknowledgement of this kind of equality suggests the possibility that there may be other morally important equalities, also deserving the name of rights, whose protection may sometimes conflict with the unfettered operation of majority rule. ${ }^{195}$

Most conceptions of democracy emphasize a necessary balance between majoritarian preferences and individual rights. ${ }^{196}$ This balance is reflected in the Constitution itself. ${ }^{197}$ To require a judge to give due deference to the value of democracy does not necessitate the judge's complete abdication in the face of majoritarian value choices. To the contrary, "democracy" takes its place, albeit a very prominent one, within the universe of reasons for action that must guide the judge's interpretive enterprise.

If any truly rational approach to decision-making requires consideration of the balance of all relevant reasons, including valueladen reasons pertaining to justice, democracy, and the like, then no value-free method of interpretation based on framers' intentions can be rationally justified, and originalism cannot be a valid theory of constitutional adjudication. Instead, judges must recognize democracy's inherent value of liberty enhancement, and give adequate weight to that value and due deference to the democratically pedigreed choices embodied in statutes at every step of the adjudicative process. The exposition of a democracy-based nonoriginalist theory of constitutional interpretation is obviously outside the scope of this Comment. But it is clear to me that proper deference to democracy requires that the judge demand very strong evidence before according to the Constitution's text an interpretation that invalidates democratic laws. As Justice Scalia has

195 Thomas Nagel, The Supreme Court and Political Philosophy: Remarks on the Afternoon Session, 56 N.Y.U. L. REV. 519, 520 (1981) (footnotes omitted) (citing ELY, supra note 140); see MARTIN EDELMAN, DEMOCRATIC THEORIES AND THE CONSTITUTION 5 (1984); MICHAEL J. PERRY, MORALITY, POLITICS, AND LAW 165 (1988).

196 See AHARON BARAR, JUDIGIAL DISCRETION 195-96 (1989); ROBERT A. DAHL, A PREFACE TO DEMOCRATIC THEORY 133-34 (1956); H. B. MAYO, AN INTRODUCTION TO DEMOCRATIC THEORY (1960); see also Erwin Chemerinsky, The Supreme Court, 1988 Term: Foreword: The Vanishing Constitution, 103 HARV. L. REV. 43, 76 (1989) (“[T]he best approach insists that the term [democracy] include both substantive constitutional values as well as the procedural norm of majority rule.").

${ }^{197}$ See, e.g., Wallace, supra note 140, at 2 ("[T] he Constitution is not entirely democratic. There are limits on what the majority may do.... [C]onstitutional protections and structures ... represent significant practical restraints on the scope of majoritarian democracy."). 
observed, the real interpretive debate, in the end, comes down not to whether originalism or some other theory is correct, but to a dispute "concerning the nature and degree of evidence necessary to demonstrate that constitutional evolution has occurred." 198 